\title{
MAGYARORSZÁG ÉS AZ EURÓPAI DÉLI OBSZERVATÓRIUM
}

\section{HUNGARY AND THE EUROPEAN SOUTHERN OBSERVATORY}

\author{
Ábrahám Péter \\ az MTA doktora, Csillagászati és Földtudományi Kutatóközpont Konkoly Thege Miklós Csillagászati Intézet, Budapest \\ abraham@konkoly.hu
}

\begin{abstract}
ÖSSZEFOGLALÁS
A csillagászat az egyik leginkább nemzetközi tudomány, ez abban is megnyilvánul, hogy az egyre nagyobb teljesítményű, egyre drágább távcsöveket több ország összefogásával építik, és a Föld legjobb asztroklímájú helyeire telepítik. Európa rendkívül sikeres nemzetközi csillagászati szervezete az Európai Déli Obszervatórium (ESO), amelynek kettős küldetése világszínvonalú obszervatóriumok közös létrehozása és fenntartása, valamint a tagországok tudományos együttműködésének elősegítése. Magyarország csillagászati jövőképének évtizedek óta központi eleme az ESO-hoz való csatlakozás. Bár erre még kormányzati jóváhagyás hiányában nem került sor, jelenleg is sok szálon kötődünk az ESO-hoz, a világszínvonalú chilei optikai-infravörös-rádiótávcsövek használatától az ESO szakértői bizottságaiban való részvételig és a műszertechnikai együttműködésig. Mindez bizonyítja, hogy a magyar csillagászat megérett az ESO-tagságra. A csatlakozási folyamat előnyeinek bemutatására a Magyar ESO Konzorcium 2019 elején széles körű felmérést végeztetett a magyar technológiai szektorban, kimutatva, hogy jó néhány magyar vállalkozás érdeklődik az ESO tenderei iránt, és általuk az éves tagdíj legalább 30\%-a visszahozható az országba. Ezekre az érvekre alapozva 2019. február óta hivatalos csatlakozási javaslat fekszik az Innovációs és Technológiai Minisztérium asztalán.
\end{abstract}

\section{ABSTRACT}

Astronomy is one of the most international fields of natural sciences, meaning also that modern telescopes are built in collaboration of countries and are placed at the most favourable astroclimatic locations worldwide. Europe has a very successful intergovernmental astronomical organization, the European Southern Observatory (ESO), which has a double mission: construction and operation of world-leading observatories, and promotion of scientific collaboration among member states. Becoming a member of ESO is perhaps the most important milestone on the future roadmap of Hungarian astronomy. While its governmental approval is still lacking, we already have multiple links to ESO: we regularly apply and carry out observations with ESO's high-performance optical-infrared-radio telescopes in Chile, are invited to various ESO expert committees, and collaborate on instrument development. All these facts demonstrate that Hungarian astronomy has reached the level of ESO compatibility. To explore the economical aspects of the membership, in 2019 the Hungarian ESO Consortium surveyed the Hungarian technology sector and revealed a number of companies interested in ESO tenders, implying that at least 
$30 \%$ of the annual fee could flow back to the country via orders from companies. Based on all the above arguments, in 2019 February a proposal was submitted to the Ministry of Innovation and Technology, to start official negotiations about ESO membership.

Kulcsszavak: csillagászat, ESO, óriástávcsövek, nemzetközi együttműködés, technológiai fejlesztés

Keywords: astronomy, ESO, giant telescopes, international cooperation, technological developments

\section{MEGFIGYELŐCSILLAGÁSZAT, NEMZETKÖZI EGYÜTTMŪKÖDÉSBEN}

A csillagászat születése óta nemzetközi tudomány, ma sincs értelme magyar csillagászatról, legfeljebb Magyarországon végzett csillagászati kutatásokról beszélni. A csillagos égbolt nem osztható fel az országok között, még az sem mond sokat egy ország csillagászati kutatásairól, hogy az északi vagy a déli féltekén helyezkedik-e el. A nemzetközi jelleget tovább erösíti, hogy az egyre nagyobb teljesítményü, egyre drágább távcsöveket csak több ország összefogásával lehet megépíteni, és a Föld legjobb asztroklímájú helyeire érdemes telepíteni.

Mivel ilyen helyszín Európában nem található, több európai ország tart fenn megfigyelési bázist más kontinensen, gyakran a déli féltekén. A legnagyobb és legsikeresebb megfigyelési bázist azonban nemzetközi összefogásban hozták létre. Ez az Európai Déli Obszervatórium (European Southern Observatory, ESO), amelyet 1962-ben öt európai ország alapított, mára pedig már tizenhat tagja van (a közelmúltban csatlakozott országok: Csehország 2007, Ausztria 2009, Lengyelország 2014, Írország 2018). A kormányközi szervezet kettős küldetést vall magáénak: olyan világszínvonalú obszervatóriumok létrehozása és fenntartása, amelyek meghaladnák az egyes országok lehetőségeit; valamint a tagországok tudományos együttmüködésének elősegítése. Magyarország nem tagja az ESO-nak.

$\mathrm{Az}$ ESO jelenleg három nagy obszervatóriumot tart fenn részben vagy egészben, mindegyiket Chilében. A legelső volt az 1969 óta működő La Silla optikai-infravörös obszervatórium. Bár itt a mai napig sok értékes kutatás zajlik, az ESO jelenleg legnagyobb teljesítményű távcsövei, a Very Large Telescope már nem itt, hanem az 1999-ben megnyílt Paranal Obszervatóriumban müködnek. A négy, egyenként $8,2 \mathrm{~m}$ tükörátméröjü teleszkóp mindegyike önmagában is a legnagyobbak közé tartozik, de lehetőség van a távcsövek összekötésére, az interferometriai módszerek segítségével így akár egy 200 m tükörátmérőnek megfelelő szögfelbontást is el lehet érni. A Chajnantor-fennsíkon felépített ALMA-rádióantenna-rendszer egyharmad arányban tartozik az ESO-hoz. Legújabban pedig Paranaltól alig $20 \mathrm{~km}$-re az ESO elkezdte a világ legnagyobb távcsöve, a $39 \mathrm{~m}$ tükörátmérőjű Extremely Large Telescope (ELT) megépítését. 


\section{AZ ESO MINT A MAGYAR CSILLAGÁSZATI JÖVŐKÉP KÖZPONTI ELEME}

A Csillagászati és Földtudományi Kutatóközpont Csillagászati Intézete több mint ötven éve múködteti a legnagyobb magyarországi obszervatóriumot a Mátrában. Bár a Piszkéstetői Obszervatórium sok eredményt szolgáltat, és az utóbbi években jelentős felújításokon ment át, hosszabb távon behatárolja müszereink teljesítőképességét a derült éjszakák száma, a légkör átlátszósága és vízgőztartalma, valamint a környező települések által okozott fényszennyezés. A Piszkéstetői Obszervatóriumban az adottságainak legjobban megfelelö észlelések folynak (időbeli változások, tranziens jelenségek követése, naprendszerbeli égitestek megfigyelése). Azonban a hazai csillagászat kutatási profilja ennél lényegesen szélesebb, és évtizedek óta folyamatosan igényli a hozzáférést nagytávcsövekhez, a Magyarországról a légkör vízgőztartalma miatt elérhetetlen infravörös színképtartományhoz és az itthon nem alkalmazható megfigyelési technikákhoz (például: polarimetria, interferometria). Mindezt csak nemzetközi együttmüködésben lehet megvalósítani, így magától értetődő, hogy a magyar csillagászat jövőképének legalább két évtizede központi eleme az ESO-hoz való csatlakozás.

Magyarország ESO-hoz történő csatlakozásának kérdése az ESO korábbi főigazgatója, Catherine Cesarsky 2003-as magyarországi látogatása óta változó intenzitással napirenden van. 2016 júniusában az ESO akkori főigazgatója, Tim de Zeeuw Magyarországra látogatva találkozott a magyar csillagászati közösséggel, és megtekintette a Piszkéstetői Obszervatóriumot. Az ESO 2017-ben kinevezett jelenlegi föigazgatójával, Xavier Barçons-nal is megtörtént a személyes kapcsolatfelvétel. A magyar kormányzati szervekkel is történtek egyeztetések, amelyek eddig sikertelenek voltak a belépési díj és az éves tagdíj biztosításával kapcsolatos kérdések miatt.

Az ESO a csillagászati kutatás legsikeresebb nemzetközi szervezete, világvezető mind a tudomány területén, mind pedig az alkalmazott müszaki-ipari technológia tekintetében. A magyarországi csillagászat számára az ESO-hoz való csatlakozás sok területen kínálna jelentős előnyöket:

- rendkívül sokoldalú müszerpark, optikai-infravörös-(szub)milliméteres hullámhossztartomány, folyamatos müszerfejlesztések, észlelési támogatás,

- hozzáférés nagytávcsövekhez,

- az ESO tulajdonában lesz hamarosan a világ legnagyobb távcsöve (ELT),

- nincs agyelszívás, a kutatók a saját intézetükből vesznek részt az ESO munkájában, viszont a tagság gyakran feltétele külföldi posztdoktori kutatók idevonzásának,

- fokozza az egyéb asztrofizikai programok (ESA, LIGO) eredményességét,

- nemcsak távcsőidőt biztosít, hanem beleszólást enged az európai csillagászat jövőjébe, és iskolát nyújt a projektalapú kutatómunka, gondolkodásmód elsajátításához, 
- oktatási programok: ESO Summer Astrocamp; ESO Summer Research Programme; ESO Student Programme, ESO Postdoc Fellowship.

Magyarország részt vesz és jelentős szerepet vállal több jelentős nemzetközi csillagászati projektben, mint a European Space Agency (ESA) asztrofizikai missziói vagy a Laser Interferometer Gravitational-Wave Observatory (LIGO) gravitációshullám-detektor. Ezek a programok élvonalbeli adatokat szolgáltatnak, azonban többnyire behatárolt hullámhossztartományban és kisszámú megfigyelési móddal, így a rájuk épülő tudományos programok a teljes asztrofizikának csak kis részét fedhetik le. Az ESO ettől eltérö filozófiát követve igyekszik minden fontos megfigyelési technikára lehetőséget adni, hogy egy adott objektumot vagy csillagászati jelenséget minél több szempont alapján, minél teljesebben meg lehessen vizsgálni. Ezért az ESO nem helyettesíthető a fent említett programokkal, viszont a tudományos kutatás szempontjából ideálisan kiegészítik egymást.
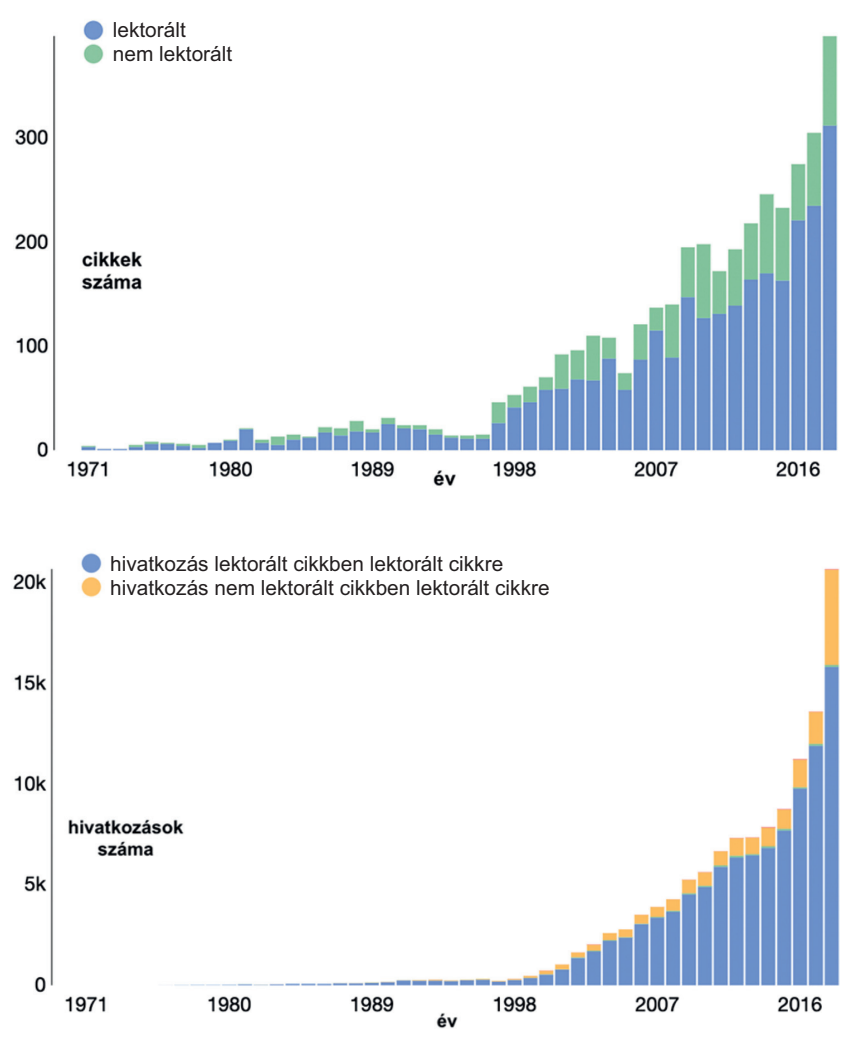

1. ábra. Magyar csillagászok által vezető szaklapokban publikált cikkek számának növekedése (fent), illetve a magyar szerzőségü publikációk idézettségének emelkedése (lent), éves bontásban (az Astrophysics Data System interaktív oldalon összegyüjtött adatok alapján) 
Az ESO föigazgatója legutóbbi látogatásakor, 2016-ban áttekintést kapott a magyar csillagászat elmúlt évekbeli gyors ütemü fejlődéséröl, amely megmutatkozik a publikációszám és idézettség gyors emelkedésében (1. ábra), valamint az elnyert nagypályázatok és díjak számában (4 ERC, 7 MTA Lendület, 1 TÁMOP, 2 GINOP, nagy presztízsű egyéni díjak). A mintegy száz szakcsillagász és száz egyetemi vagy doktori hallgató az ESO-csatlakozást követően várhatóan évi öttíz nyertes magyar távcsőidő-pályázatot fog majd benyújtani, így az ESO müszerein alapuló hazai publikációk száma várhatóan jelentősen megemelkedik. Tim de Zeeuw kiemelte, hogy a magyar csillagászat szakmai színvonalát tekintve megérett az ESO-tagságra, és az ESO részéről szívesen látott tagjelölt.

\section{KAPCSOLATOK MAGYARORSZÁG ÉS AZ ESO KÖZÖTT}

Annak ellenére, hogy nem vagyunk ESO-tagország, az elmúlt években folyamatos együttmüködés alakult ki Magyarország és az ESO között. Hazai kutatók rendszeresen pályáznak megfigyelési lehetőségre az ESO távcsövein, és az évi két szemeszter mindegyikében átlagosan két-három pályázatot nyernek el. 2014-től öt évig futott egy sikeres MTA Lendület program, amely az ESO ALMA rádióantenna-rendszerével végzett mérésekre alapozta tudományos kutatásait (Kóspál Ágnes). Rendszeresen jelennek meg ESO-mérésekre alapozott publikációk magyar szerzők tollából, részt veszünk az ESO által szervezett konferenciákon, és benne vagyunk több ESO-égfelmérésben. Időnként magyar csillagászok utaznak La Sillára vagy Paranalra megfigyeléseket végezni. Felkérésre rendszeresen végzünk szakmai szakértő munkát az ESO számára. Több magyar csillagász volt tagja a La Silla/ Paranal távcsőidő-elosztó bizottságnak (Ábrahám Péter, Kiss László, Kóspál Ágnes, Maria Lugaro, Szabó Róbert) vagy az ALMA távcsőidő-bizottságnak (Kóspál Ágnes). Az ESO Studentship programban több magyar doktori hallgató tölthetett el egy-két évet az ESO garchingi (Németország) központjában.

A kapcsolatok akár impresszívnek is tekinthető jelenlegi szintje sok magyarországi kutató áldozatos munkáját takarja. Azonban fontos leszögezni, hogy az ESO-müszerekhez való hozzáférésünk saját jogon nem lehetséges, csak ESO-tagországbeli kollégákkal való együttmüködéseken keresztül érhető el. Ennek esetlegessége, a hozzáférési szabályok jövőbeni szigorítása komoly kockázati tényező számunkra, és az ESO-tól sem várható el, hogy egy, a közös fenntartásba nem befizető országnak hosszú távú korlátlan hozzáférést biztosítson az eszközeihez. Ezért az eddigi kapcsolat eredményeire alapozva - amelyek bizonyítják, hogy Magyarország megérett a tagságra - a jövőbe vezető út egyértelmúen a teljes jogú ESO-tagság. Ez adna csak alanyi jogú pályázási lehetőséget a világ legmodernebb távcsöveinek használatához, valamint az ESO Tanács és más bizottságok tagjaként beleszólást a további fejlesztésekbe, az európai csillagászat jövőjébe. 


\section{MAGYAR IPARI BESZÁLLIITÓK LEHETŐSÉGEI AZ ESO-BAN}

Az ESO amellett, hogy a csillagászat egyik legnagyobb tudományos központja, folyamatosan fenntartja és fejleszti a megfigyelési infrastruktúráját. A civilizációtól távoli helyszíneken világszínvonalú berendezések üzemeltetése, új generációs műszerek létrehozása és az ELT számára az új Armazones Obszervatórium kialakítása rengeteg külső beszállítót igényel. A teljes jogú tagság lehetőséget teremt a magyar gazdasági szereplők számára, hogy részt vegyenek az ESO tenderein, és az éves tagsági díj egy részét megrendeléseiken keresztül visszahozzák az országba.

Arra, hogy magyarországi müszaki tevékenységgel sikeresen hozzá lehet járulni akár a legmagasabb technológiai szintet képviselő ESO-müszerfejlesztésekhez is, jó példa a Csillagászati és Földtudományi Kutatóközpont Konkoly Thege Miklós Csillagászati Intézet (CSFK Csillagászati Intézet) részvétele az ESO új, másodgenerációs infravörös interferométere, a MATISSE (Multi AperTure midInfrared SpectroScopic Experiment) létrehozásában. Az intézet mérnökei érdemben hozzájárultak a müszer termális viselkedésének modellezéséhez, megterveztek és Magyarországon legyártattak egy tesztelésre szolgáló optikai kamerát, és szimulálták a szállítás során várható mechanikai igénybevételt. Az elvégzett munka elismeréseként a Csillagászati Intézet garantált megfigyelési lehetőséget kapott a MATISSE-müszeren.

Hogy megbízható képünk legyen arról, hány magyarországi vállalkozás mutatna érdeklődést az ESO tenderein való részvételre, 2019 elején kérdőíves felmérést és ipari hatástanulmányt végeztük az olyan cégek körében, amelyek bejegyzett tevékenységi köre átfedi az ESO tenderkiírásainak témáit. Tíz vállalkozástól kaptunk vissza támogató levelet, amelyben kimondottan kifejezik érdeklődésüket az ESO tenderein való részvételre, ha Magyarország csatlakozik a szervezethez. Vizsgálataink alapján, összevetve az érdeklődő cégek tevékenységi körét az elmúlt évek ESO-tendereinek tematikai megoszlásával és a tenderek összegével, úgy látjuk, hogy már az első évtől az éves tagdíj legalább 30\%-os visszatérülése várható Magyarország számára a vállalkozásokon keresztül.

A közvetlen megrendeléseken túl a magyar ipar jelentős tapasztalatot és know-how-t kaphat az ESO-val való együttmüködéseken keresztül, különösen a következő high-tech témakörökben: ipari automatizálás és rendszerintegráció; mesterséges intelligencia alkalmazása; mintázatkeresés nagy adatbázisokban; adatgyüjtés, -feldolgozás, -elemzés; valós idejü beágyazott rendszerek, high performance computing; lézertechnológia; speciális fémötvözetek; anyagtudomány; detektáló és képalkotó rendszerek fejlesztése; GPS-alapú időstandard. 


\section{A MAGYAR CSATLAKOZÁSI FOLYAMAT ÁLLÁSA}

Annak elősegítésére, hogy Magyarország mielőbb teljes jogú tagként csatlakozhasson az ESO-hoz, és utána a szervezeti tagság valóban elősegítse a magyar csillagászat további fejlődését, a következő szervezetek 2017. január 26-án szándéknyilatkozatot írtak alá a Magyar ESO Konzorcium megalapításáról (zárójelben az aláírók):

- MTA CSFK KTM (Kiss L. László),

- ELTE Csillagászati Tanszék (Tóth L. Viktor),

- ELTE Atomfizikai Tanszék (Frei Zsolt),

- ELTE Komplex Rendszerek Fizikája Tanszék (Csabai István),

- ELTE Gothard Asztrofizikai Obszervatórium (Szabó M. Gyula),

- Szegedi Tudományegyetem Fizika Intézet és Bajai Obszervatórium (Vinkó József),

- MTA XI. Fizikai Tudományok Osztálya Csillagászati és Ürfizikai Tudományos Bizottság (Szabados László).

A Magyar ESO Konzorcium javaslatot készített Magyarország kormánya számára az ESO-csatlakozásról, amelyhez az ESO-adminisztrációtól megkapta a magyar belépés pénzügyi feltételeit. Ennek alapján a csatlakozáskor Magyarország egyszeri belépési dijat fizet, amellyel megváltja a szervezet vagyonából arányosan rá eső részt. Az arányosítás a nettó nemzeti jövedelem (NNI) alapján történik, amely szerint Magyarország részesedése az ESO költségvetéséből 2018-ban 0,67\% volt, 2019-ben mintegy 0,69\%. Az egyszeri belépési díj a fentiek alapján hozzávetőleg 8,5 millió euró, amelynek kifizetése hosszabb időszakra, akár tíz évre széthúzható. Ezenkívül a belépés után az ESO müködési és fejlesztési költségeire éves tagdíjat kell fizetni, amelynek összege kevesebb mint 1,3 millió euró évente.

A Magyar ESO Konzorcium javaslatát az elmúlt évek során több alkalommal is benyújtotta a Nemzeti Kutatási, Fejlesztési és Innovációs Hivatalhoz, részben a hivatal által nemzetközi szervezetekben való tagságra kiírt pályázat keretében, részben közvetlenül, rendkívüli elbírálást kérve. Az utóbbi eljárást az tette szükségessé, hogy az ESO 2019-ben áttekintette a további tagjelöltekkel kapcsolatos eljárásrendjét, és ennek során megvitattak egy olyan javaslatot is, miszerint az 1\%-os részesedést el nem érö tagjelölteknek nem teljes jogú tagságot ajánlanak, hanem egy tudományos partnerségi programot. Amennyiben a jövőben ez megvalósul, az Magyarország számára komoly visszalépés lenne, mivel a partnerség nem tenné lehetővé a magyar gazdasági vállalkozások részvételét az ESO tenderein, így az éves tagdíjból semmi nem lenne visszapályázható. Hogy Magyarország még teljes jogú tagként léphessen be a szervezetbe, a csatlakozási szándék miniszteri szintű mielőbbi bejelentése szükséges, ez indokolta a csatlakozási javaslat és a már em- 
lített ipari hatástanulmány újabb benyújtását az NKFIH-nak 2019. február 19-én. A kézirat lezárásáig a javaslatra hivatalos válasz nem érkezett.

Az ESO-csatlakozás és az azt követő felzárkózási időszak minél sikeresebbé tételére a magyar csillagászközösség már most is sok mindent megtehet. A legfontosabb az ESO müszereinek rendszeres használata (többnyire ESO-tagországbeli kollégákkal együttmüködve), hiszen így épül be fokozatosan az ESO a magyar csillagászati kultúrába. Fontos, hogy az egyetemi oktatásban hangozzék el minél több információ az ESO-ról, legyen a fiatal generáció számára magától értetődő az ESO műszereire való pályázás. Ha mód nyílik rá, kezdeményezni kell a müszerfejlesztésekben való magyar részvételt. A személyes kapcsolatok kiépítését segíti az ESO által szervezett konferenciákon, iskolákon való részvétel. Nagy előrelépés, hogy Magyarország bekerült az ESO ismeretterjesztő programjába, így most már az eso.org oldalon a magyar nyelv is kiválasztható, és az ESO sajtóközleményeit folyamatosan fordítjuk magyarra Szabó Róbert vezetésével. Nem lehet eléggé hangsúlyozni az ESO Studentship Programme-ban való rendszeres magyar részvétel jelentőségét. E kétoldalú képzési formában egy magyarországi egyetem doktori programjába beiratkozott hallgató egy-két éves vendégkutatását finanszírozza az ESO. A Garchingban vagy Santiago de Chilében töltött idő során a hallgató kapcsolatrendszert épít, és elsajátítja néhány élvonalbeli ESO-müszer használatát. Szinte felbecsülhetetlen annak a pozitív következménye, ha a magyarországi csillagász PhD-hallgatók jelentős százaléka részt venne ebben a képzésben, s a következő kutatógeneráció már magától értetődően használná az ESO berendezéseit. Végül nagyon fontos annak a hangoztatása és megértése, hogy az ESO-csatlakozás nemcsak a müszereken való megfigyelési lehetőség megszerzéséröl szól, hanem ennél sokkal több: az ESO olyan szervezet, amely oktatási programjain, konferenciáin, technikai és tudományos projektjein keresztül a legmodernebb kutatási módszerekre tanítja a részt vevő tagállamokat.

\section{AZELT ÉS A METIS}

Az ESO által a Paranal Obszervatóriumban üzemeltetett négy egyforma, 8,2 m tükörátmérőjü nagytávcső már most is a megfigyelési csillagászat egyik legnagyobb teljesítményü müszeregyüttese. A továbblépés érdekében azonban már elkezdődött a 39 m tükörátmérőjü Extremely Large Telescope megépítése Paranal szomszédságában (2. ábra). A Föld legnagyobb távcsöve tulajdonosaként az ESO 2024 után világvezető pozíciót foglal el, és ebben részesülhet Magyarország is tagsága esetén. Az új óriástávcső müszereinek fejlesztése már folyik. A CSFK Csillagászati Intézet mérnökei egy most induló holland-magyar együttmüködés keretében hozzájárulnak az ELT középinfravörösben észlelő müszere, a Mid-infrared ELT Imager and Spectrograph (METIS) megépítéséhez. Reményeink sze- 
rint a müszer elkészültét és az ELT „első fényét” Magyarország már az európai csillagászközösség teljes jogú tagjaként ünnepelheti.

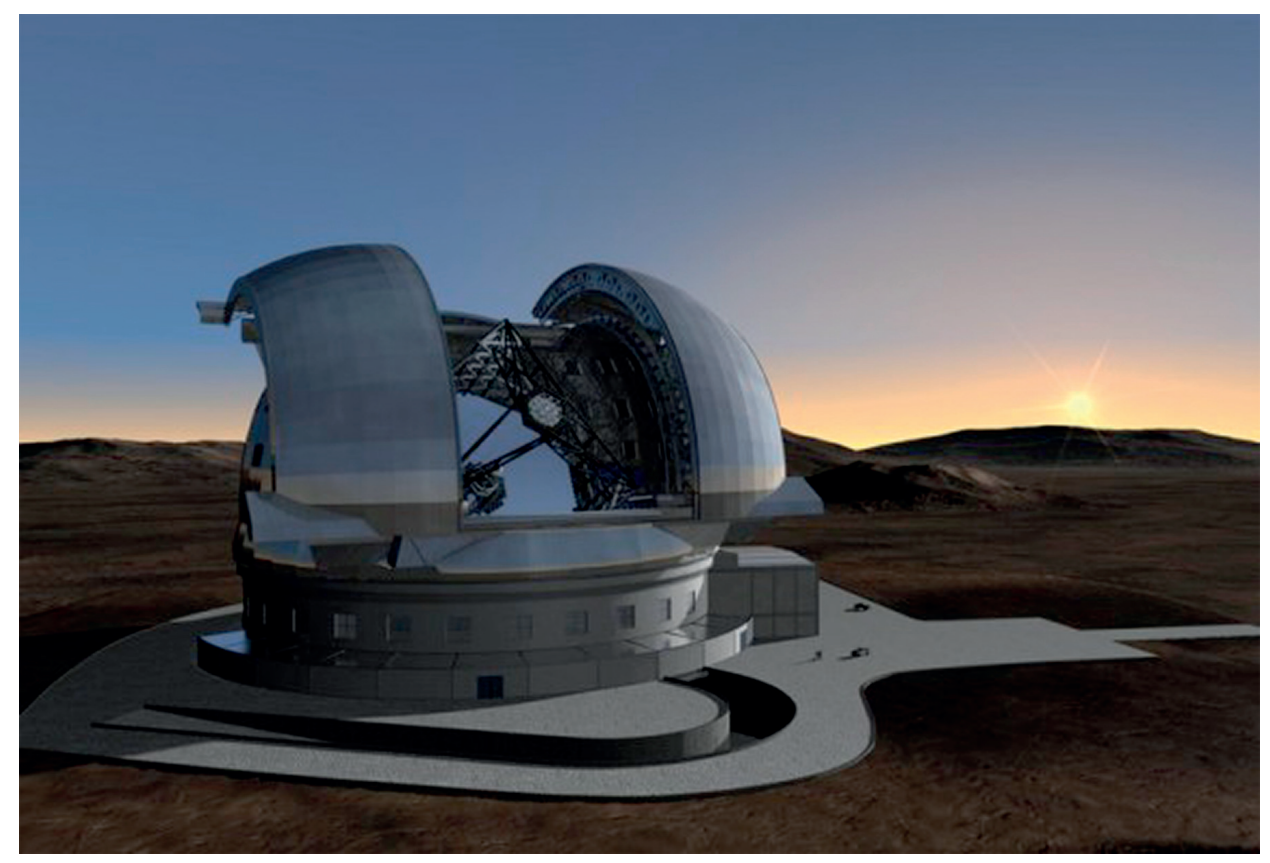

2. ábra. Az ESO ELT távcsövének látványterve. A 2024 után elkészülő óriástávcső a világ csillagászatának zászlóshajója lesz (ESO) 